\title{
The Manifestation of Indonesian Democracy; Between Pancasila State of Law and Islamic Nomocracy
}

\author{
Sarip \\ Faculty of Law of Universitas Muhammadiyah Cirebon \\ Jalan Tuparev Nomor 70 Cirebon \\ Emailsaripanisa@yahoo.co.id
}

\begin{abstract}
The state of Pancasila law is a tool for people who have the power to regulate human relations in society and regulate the symptoms of power in society. As a country with the largest Muslim population in the world, Indonesia does not make Islam its legal basis. The Islamic Nomocracy and its values are embedded in the state of Pancasila law, as well as manifestation of democracy itself. Through these hyphoteses, the writer tries to find a common flateform between Pancasila and the Islamic Nomocracy in the formation of Indonesian democracy. This classic problem requires special attention, because the debate always triggers reactions and actions. Islam as a religion with complex system of living is believed to be a powerful mechanism in dealing with various life problems encountered. The Shari'ah consists of a combination of pre-Islamic customs and habits with principles and laws originated from the Qur'an and authentic prophetic tradition. Islamic scholars try to form Islamic teachings as ethical and national policies. Even so, the principle of the Pancasila state was accepted as final, at least there were Islamic nomocracy values embedded in the Pancasila while at the same time they contributed to build Indonesia's democracy as a modern country. The theological values in the Pancasila and islamic nomocracy should not be a mere formal rule, but should address the substance of democracy in Indonesia. The rule of law must be supported by a democratic system because there is a clear correlation between the rule of law which relies on the constitution, and the sovereignty of the people which is carried out through a democratic system. In a democratic system, people's participation is the essence of this system. However, democracy without legal regulation will lose form and direction, while law without democracy will lose meaning.
\end{abstract}

Keywords: State of law; Pancasila; Islamic Nomocracy; Democracy

\section{A. INTRODUCTION}

The state consists of a collection of individuals who have rights and obligations that interact with each other to meet their individual needs. As a large organization, it is only natural that Indonesia has a government and government that is formed and equipped with the power to make and implement binding regulations, to achieve common goals (Putra, 2017; Soemarsono, 2007). Regulations that are binding starting from the central to the lowest levels must not conflict with the Pancasila which is used as the foundation of the state, then Indonesia is known as the state of Pancasila law (Nurita, 2015). 
The state of Pancasila law is a tool for people who have the power to regulate human relations in society and regulate the symptoms of power in society (Chandranegara, 2015). With regard to the Indonesian state it can be assumed that the government is the personification of the state, can act on behalf of the state, which can force its authority legally against all groups in society (Fuady, 2009). Indonesia as a modern country that has a Pancasila foundation is a welfare state (Wijaya, 2015). The state of Pancasila law carries the public interest for prosperity and prosperity based on justice, constantly getting the spotlight, especially from the standpoint of Islamic nomocracy (Sigit Riyanto, 2012).

The many debates relating to Pancasila and Islamic nomocracy are phenomena and problems of Indonesian state administration which cannot be considered small in achieving democracy. Awareness of the state of Pancasila law is not limited to knowing the five precepts, but understanding the consequences as a modern law state. The state of Pancasila law and the nomocracy of Islam that is questioned is not how to make the law conscious society and become part of its social awareness, but how the Indonesian administrative problem can harmonize both. In line with the opinion of Ilham Yuli Isdiyanto, that the application of the rule of law is not only a matter of formal legality, but the validity within the community materially also needs to be considered (Yuli Isdiyanto, 2018). Likewise, when naming the state of Pancasila law and the nomocracy containing the values of Islam in Indonesia, it is not merely formality, but substantively can be realized in a democratic society.

This study discusses and elaborates the theoretical issues on the state of Pancasila law and Islamic nomocracy strictly. This study will provide a description on the relationship between the state of Pancasila law and the nomocracy of Islam, especially to unravel the state of Pancasila law based on Islamic nomocracy, and can realize the values of Pancasila both seen by the nomocracy of Islam in the realization of Indonesian democracy. Thus, the main problem of the study is to know the state of the Pancasila law with Islamic nomocracy from the perspective of the rule of law and their current manifestation of democracy.

\section{B. DISCUSSION AND ANALYSIS}

\section{The State of Pancasila Law}

In any part of the world the state of the Pancasila law is unrecognized term. This term is only known in the Indonesian law. The term state of Pancasila law is basically a term that exists in Indonesian state administration which is in conflict with the legal countries in the world. The character of the state of Pancasila law is the basic values taken from the Indonesian culture and contained in the five principles of Pancasila. The concept of the state of Pancasila law as stated in the Pancasila which contains:
a. Believe in one God;
b. Humanitarianism;
c. Nationalism; 

d. Democracy;
e. Social justice.

The five basic state laws as a characteristic of the state of Pancasila law adopted by Indonesia become a benchmark and at the same time often get the spotlight. The spotlight on the state of Pancasila law does not escape the debate in Indonesia's own constitution. The debate about Indonesian constitution has never ended since the beginning of independence until the fourth amendment to the 1945 Constitution, namely themes that present the state of Pancasila law and the theme of the rule of law based on Islamic Sharia. Two major themes always adorn the scientific literature about the state of Indonesian law can be regarded as very reasonable thinking. The thought touched constitutional substance, in the end a fairness saw again the study of the state of the Pancasila law and Islamic nomocracy. Both the state of Pancasila law and the nomocracy of Islam often get the spotlight in accordance with divine values in carrying out the Indonesian state administration.

The state of Pancasila law which in the development of Indonesian constitution is often debated by academician. It is a natural thing where the state of Pancasila law is faced in two sides, namely the religion and soul of the Indonesian nation itself. However, in the view of Islam itself, the debate over the state of Pancasila law is often identified with Islamic nomocracy as a reflection of the life of the nation and state. The reasonableness of the debate about the state of Pancasila law and Islamic nomocracy can be seen from two sides, namely:

a. The state of Pancasila law tries to explore the values embedded in Indonesian society (Wijaya, 2015);

b. Islamic Sharia explores the values of Islamic teachings based on the majority of Indonesian people who are Muslim and Islamic nomocracy (Zuhraini, 2014).

Both are very clear both the state of Pancasila law and in the nomocracy of Islam cannot override values relating to divinity. As a consequence, the state of Pancasila law which tries to accommodate Islamic nomocracy values is inseparable. The basic content contained in the state of Pancasila law rests on five provisions contained in the Pancasila, namely (Dayanto, 2013):

a. The theological Principle;

b. The principle of humanity;

c. Principle of unity;

d. Principle of consensus agreement; and

e. Principles of community justice.

The five precepts that live the life of the nation and state then become a mirror in the state of Pancasila law that distinguishes it from other legal countries in the world. Then the state of Pancasila law as an identity described in the constitution is also used as identity politics (Sarip, 2018). It is said that identity politics is concerned 
with distinguishing characteristics that distinguish it from the existing legal state in the world. Likewise, Islamic nomocracy, as said by Muhammad Tahir Azhary, is a legal state that has general principles which include (Azhari, 2015):

a. The principle of power as a mandate;

b. The principle of deliberation;

c. Principles of justice;

d. The principle of equality;

e. Principles of recognition and protection of every human right;

f. The principle of free justice; The principle of peace; The principle of welfare; and

g. The principle of obedience to the people.

The legal state of Pancasila as the state identity and nomocracy of Islam as stated by Muhammad Tahir Azhary basically does not have substantial contradictions (Azhari, 2015). As evidence of the absence of substantial opposition, it can be seen from the nomocracy's historical Islam itself. The origin of Islamic nomocracy is seen in the history of the Turkish state as a country that once practiced the khilafah state, indicating that Islam as a major influential religion also had the concept of a rule of law, known as Islamic nomocracy. It is precisely the substance of Islamic nomocracy values that have been adopted by the Indonesian state of Pancasila law, although formally it is not clearly indicated by these Islamic nomocracy values.

Both the state of Pancasila law and the nomocracy of Islam can basically be approached by looking at the theory of state science, namely about theology. The state science theory of a country that stands for theological reasons, it is called the country as a theocratic state (http://www.negarahukum.com/hukum/nomokrasi-islam.html, June 20, 2018 Up Date). But the theory commonly introduced by state science as the origin of the creation of the state, that the nomocracy of Islam is a theocratic concept denied by the authors of Islamic law, arguing that the mention of theocracy is a form of government that recognizes God or gods as close rulers. So that theocracy is more suitable to be given to a Vatican-led country, like what happened in Rome. Apart from these debates, it is this basic idea of values that cannot be lost both in the state of Pancasila law and in Islamic nomocracy.

This point of view is more caused by Islamic teachings being very egalitarian and prioritizing equality, so that it is impossible to justify a group of religious experts claiming to be God's representatives to be able to rule in a country. This reason is reasonable for the nomocracy of Islam and the state of law of Pncasila because it is impossible to equate the Creator with the results of his creation. The disagreement of the state of Pancasila law on theocracy is also shown in fact on the basis that it impossible for a representative of God to control power in the name of God but the values of God that exist and must be carried out in a state-based Pancasila. 
The state of Pancasila law cannot be separated from the development of the rule of law itself as in the development of a modern constitution. Developments in modern law and constitution, for Islamic law will adapt to modern law (modern jurisprudent) both within the rule of law and rechstaat. Therefore, in drafting a country's constitution, both the rule of law and rechstaat cannot be separated from the distinctive characteristics of Islamic law. Likewise, with the state of Pancasila law that cannot be separated from the development of modern constitution and the development of Indonesian society itself which has a different identity from other legal countries.

The benchmark of the state of Pancasila law which is very risky is its own divine principle that is in line with the general principles of Islamic nomocracy as said by Muhammad Tahir Azhary which emphasizes the thoughts of the state of Ibn Khaldun and is not explicitly stated as in the state of Pancasila law. However, at least the oneness of god principle in Islamic nomocracy is derived from Ibn Khaldun, who stated that in Islamic nomocracy both shari'ah and law are based on human ratios, both function in the state (Azhari, 2015). Evident from the power in Islamic nomocracy, that power is a gift or favor of Allah. This means that power is a mercy and happiness both for those who accept that power and for their people.

The Islamic legal system with its comprehensive nature is found in the constitutional aspect called Al-Ahkām Al-Sulțāniyah. The thought of the state was put in place by a well-known Islamic thinker, Ibn Kaldun. Ibn Khaldun has discovered a state typology by using a benchmark of power, namely the natural human condition and civilized human condition as stated by Ibn Khaldun, which was quoted by Muhammad Tahir Azhary. argues that there are two kinds of legal states, namely (Azhari, 2015):

a. Siyāsah Dīniyah which is translated into Islamic nomocracy;

b. Siyāsah 'Aqliyah which is translated into secular nomocracy

Both function in the country, even though they have met the criteria of the legal state according to the general concept of statehood, our state scholars still propose the concept of a legal state based on Indonesian context. In addition, the state of Indonesian law has one distinctive element that distinguishes it from other state of law countries that is the Pancasila (Soemarsono, 2007). The Proclamation of August 17,1945 , since then also Indonesia formally declared itself a democratic legal state. Explanation of the 1945 Constitution that Indonesia is a country based on law (rechtsstaat) not a state based on mere power (machtaat). The third Amendment of the 1945 Constitution of the Republic of Indonesia which was carried out by the MPR in 2001 confirmed, reaffirmed the inclusion in the Body of the 1945 Constitution. That is, the statement was no longer in the explanation, "Indonesia is a legal state" (Article 1 Paragraph (1) The 1945 Constitution) is not a state of power. Furthermore, it is also emphasized that, "Sovereignty in the hands of the people and carried out according to the Constitution (Article 1 Paragraph (2) of the 1945 Constitution). 
In addition, also in the Preamble of the 1945 Constitution of the Republic of Indonesia in the fourth paragraph affirms that, "... then the Indonesian national independence was drawn up in a State Constitution of the Republic of Indonesia which has people's sovereignty ..." (fourth paragraph of the 1945 Constitution). The idea of the rechtsstaat (state of law) has been developed by Ancient Greek philosophers which basically relied on the Continental European legal system and were popular in the 17th century because of the situation and social political conditions in Europe were dominated by absolutism. The idea was actually pioneered by Immanuel Kant and Frederich Julius Stahl (Sarip, 2018). Kant understood the rule of law as a night guard of the state (nachtwakersstaat). That is, the country with the duty to maintain public order and security.

At first Plato argued that it was possible to realize an ideal state to achieve goodness which is rooted. Therefore, power must be held by those who know goodness, namely a philosopher (the philosopher king). On another occasion Plato also stated that what could be realized was the second best form that placed the rule of law. Governments that are able to prevent the deterioration of one's power are governed by law. Plato's state goal according to Aristotle is to achieve the best life that can be achieved with the rule of law (Asshiddiqie, 2008).

It is an ideal country in the 20th century when all state activities are based on law (Wahyono, 1986). According to Padmo Wahyono, the articulation of this understanding always evolved in accordance with the level of intelligence of a nation. Therefore, Padmo Wahyono adheres the formulation as outlined by the founders of the Constitution, that Indonesia is a country based on law, with the formula "Reschtaas" assuming that the pattern taken does not deviate from the definition of the rule of law in general which is adjusted with the state of Indonesia (Al-Atok, 2016). This means that it is used with a measure of life view and state view. Thus, it is quite clear that Indonesia is a democratic legal state. It's just that at the level of implementation it is still talked about by many groups.

The idea of state law, which is a law that is used as a basis for various branches of government and which they must obey in exercising power, is a bridge between arbitrary despotic absolutism and developed constitutionalism. The state dissolves in various kinds of powers that are formally united by the constitution and even by the will of the people as seen from the programs and activities of political parties. In the politics of constitutional democracy, all laws can be seen based on the hierarchy of legal sources, the highest of which is the constitution, while the lowest is the steps taken by the emergency authorities to resolve concrete situations. In the midst of laws and regulations, the have been questions about compatibility between lower norms and higher ones are decided by the competent court.

Based on these conditions indicated that the law denies its history. In the end, the law is stuck on formal rules that pay little attention to the history of the law itself. 
Legally, in formal form is trapped in legislation as an illustration in Indonesia today, the atmosphere of the legal field is very confusing, due to the countless local variations. The 1945 Constitution applies as a law that applies to the public in Indonesia which has experienced four amendments. Amendments to the 1945 Constitution were not carried out by changing the sound of the Pancasila which was considered a feature of Indonesian law. This situation is in line with the realization of general awareness as revealed in the flow of legal history. It is like what Satjipto Rahardjo said, "the law develops in line with the growth, and becomes stronger together with the people supremacy, and it will decay when the nation loses its nationalism" (Rahardjo, 2006).

With regard to the state of Pancasila law which does not reducing or adding more than five Precepts means that if Pancasila is changed then it can automatically be said that the Indonesian people will lose their nationality. The distrust toward lawmakers in Indonesia encourages the desire to replace the state of Pancasila law with the concept of Islamic nomocracy (Rahardjo, 2006).

\section{The Pancasila Nomocracy}

The Pancasila Nomocracy is very clear in the first precepts of the One Godhead. The term legal state in Indonesian literature is a direct translation of rechtsstaat. The same thing was stated by Notohamidjojo that, with the emergence of the main ideas formulated in the constitutions of the 9th century, the term "legal state" or "rechtsstaat" arose (Oemar Notohamidjoyo 1970: 27). In the United Kingdom the designation of state law (rechtsstaat) is the rule of law, in the United States, pronounced as the government of law, ut not man (Azhari, 2015). The two terms both are rechtsstaat and etat de droit are known in Continental countries, while in Anglo Saxon countries use the the rule of law term. While the term socialist legality is known in countries that have communism (Effendi, 2005).

United Kingdom, United States and other countries that followed their national pattern rejected the existence of a special court such as the administrative court in the rule of law. They prioritize equality in the law so there is no need to differentiate in the court forum. In addition, Muhammad Yamin argues that, the Republic of Indonesia is a rechtsstaat government of laws where written justice applies, not a police state or military state, where police and soldiers hold the government and justice, nor is the state of power a place gun power and body strength are arbitrary (Azhari, 2015).

Jimly Asshiddiqie uses the term nomocracy as a legal state equivalently. He explained that, the ideas of the rule of law, besides being related to the concept of rechtsstaat and rule of law, also relate to nomocracy. The term of nomocracy can be compared with demos and cratos or kratien in democracy. Nomos means the norm, while kratos is the power. The determining factor concept in the implementation of 
power is the norm or law. Therefore, the term nomocracy is related to the idea of legal sovereignty or legal principles as the highest authority (Asshiddiqie, 2008).

If we try to review historical legacy about the law, we will find various concepts regarding the rule of law. In addition to the concept of the rule of law as stated above, there is still the concept of the state of Pancasila law, which is the basis of the philosophy of the Indonesian state which places the Almighty God as the prime cause. In contrast to the Western legal state, both the rechtsstaat concept and the rule of law place dignity of man and liberalism as the main elements and the separation between church (religion) and the state.

The principle of divinity and the role of religion strongly determine the substance of the state of Indonesian law, even in the 1945 Constitution, religious values are one measure to limit basic freedoms through law. The Pancasila State also emphasizes the significane of the deliberateve principles and harmony in solving every state problem. Therefore, Muh. Tahir Azhary said that the reference of five concepts of the rule of law were specifically found as follows (Azhari, 2015):

a. The concept of the rule of law according to the Qur'an and Sunnah which is called by the Islamic Nomocracy;

b. The concept of the rule of law applied in Continental European countries (Netherlands, Germany and France) is called as rechtsstaat.

c. The concept of a legal state is expected in Anglo Saxon countries, such as in Britain, the United States as the rule of law;

d. The concept of a legal state is expected in communist countries, such as in the Soviet Union (now Russia) as the Socialist Legality

e. The concept of a legal state that is expected in Indonesia called the state of the Pancasila law.

From a number of views above, it can be understood that, the term legal state besides known as rechtsstaat and rule of law, is also known as monocracy, which means the same as state law, the core of the formula, is that the law impelementation in a state law must be formulated democratically, or basen on people aspiration (Wahyono, 1986). According to Mahfud. MD, the Republic of Indonesia is not only rechtsstaat but also the rule of law. Therefore, the elimination of the rechtsstaat sentence after the amendment to the 1945 Constitution is not merely a semantic or grammatical problem but also involves a substantive and paradigmatic problem (Mahfud MD, 2010). It is known that, the both terms namely rechtsstaat and the rule of law are translated into Indonesian in the similarly meaning, eventhough, terminologically both terms rechtsstaat and the rule of law have a different concept and institutionalization.

If the law is understood rigidly and narrowly in the sense of mere legislation, surely the definition of the legal state developed is also narrow and limited and does not necessarily guarantee substantive justice. Because of that reason, in addition to 
the rule of law term by Friedman, there is also developed the term 'the rule of just law' to ensure that in our understanding of the rule of law there is an understanding of justice that is more essential than merely functioning legislation in a narrow sense. It is emphasized that, even if the term used remains the rule of law, that broad understanding is expected to be included in the meaning of the rule of law which is used to refer to the conception of the state of law today (Asshiddiqie, 2008).

Based on the above expression, Jimly formulated 12 basic principles which are the main pillars of upholding the modern state refering the rule of law, or rechtsstaat in the true sense. The 12 main principles are (Asshiddiqie, 2008):
a. The existence of law supremacy;
b. Equality before the law;
c. The application of the principle of legality;
d. Effective limitation of power;
e. The guarantee of independentt power operationally;
f. The existence of free and impartial judiciary;
g. The availability of a state administration justice mechanism;
h. The existence of a constitutional justice mechanism;
i. Protecting human rights;
j. The democratic rule and law system, democratische rechtsstaat, is guided by;
k. served as a means of people's welfare (welfare-rechtsstaat);
l. Transparency and social control.

If the 12 principles above are related to the Indonesian state, then, Jimly suffices to become 13 main principles, namely the principle of believing in one God is reflected in the first principle of Pancasila (Asshiddiqie, 2008). As a legal state, Indonesia accepts the principle of legal certainty in rechtsstaat as well as the principle of a sense of justice in the rule of law and spiritual values of religious law. Such written law with all procedural requirements must be put in the context of upholding justice. Therefore, written provisions can prevent the realization of justice which is abandoned (Mahfud MD, 2010). Utrecht distinguishes between a state of formal law and a state of clerical law, with a material law state or a modern law state. The formal legal state or the clerical legal state involves formal and narrow legal terms. That is, the law is only seen from written legislation. While the material law state or a modern law state, namely the material law state which is more recent also includes an understanding of justice in it.

Friedman distinguishes between rule of law in the formal sense, namely in the sense of "organized public power", and rule of law in the material sense, namely "the rule of just law". This distinction is intended to emphasize that in the concept of the rule of law, justice will not necessarily materialize substantively, because people's understanding of the law itself can be influenced by the meaning of formal law and can also be influenced by the flow of material law. 
The 1945 Constitution of the Republic of Indonesia has directed that law enforcement in Indonesia in principle adheres equally to the good aspects of the concept of rechtsstaat and the rule of law at once, namely ensuring legal certainty and also enforcing substantial justice. Moreover, the 1945 Constitution of the Republic of Indonesia also emphasized the principle of benefits, namely the principle that requires that every law enforcement must be beneficial and does not cause harm to society, nation and state (Syarkawi, 2012).

In line with the development of the national and constitutional life of the Republic of Indonesia after the reformation, through the amendments of the 1945 Constitution, the term rechtsstaat was clearly and explicitly stated in the Body of the 1945 Constitution which before the amendment was only found in the 1945 Constitution that is a legal state, a democratic state that is not authoritarian. Beside the third amandement in 2001, there was an emerging institution at court authority that is Judicial Court. This emphasized the standing of state by the law and constitutionalism. Contextually not only those people who are engaged with the law can be processed and reviewed, but the government, and contradictory acts. The meaning is that the task of judicial court is making sure the contradictory acts unexisted.

Every single act or regulation that is legalized wtih the authority should give clear direction for the society and does not violate the higher degree of law hierarchically (Djafar, 2010). From this point, the consituional court becomes the only controller and interpretor. Observing the court institutions with the act of corruption and abuse of power that violate the justice values, there arose many controvercial terms such as court mafia, court transaction systematically that the supreme court supervision can not figure out those problems.

This condition decreases the public trust toward court institution. In line with that third amandement, Judicial Commission emerged for supervising the court, enforcing the law, maintaning the nobility of court and judge's behaviors. With those authorities of Judicial commission, authomatically all the judges running for the court are under the commission supervision except the judges of Judicial Court.

The existence of new insituions such as Judicial court and Judicial Commission emphasized Indonesia as a democratic state of law not the authoritarian and repressive ones. In a democratic state, the law should be referred as the highest reference in all government processes (Asshiddiqie, 2010). Logical consequence of the above explanation is that all goverment and governance processes to assure the people's welfare and their wealthy people must be based on the law. Thus, it is necessary that the state together with its system should be based on constitution based (candranegara 2014: 60). It is necessasry to be known, the existence of the constitution is to make clear aims in order to running the tasks and authorities 
(Mahendra, 1996). So that, the existence of constituton or the 1945 constitution of the republic of Indonesia is the highest base constitution and it legalized as the democatic state of law (Hakim, 2010). In this regard, the state places the law as the government bases of this state.

\section{A manifestation toward Indonesian democracy}

Democaratic state of law is always connected and integrated with three substances: constitutions, democracy and the law. Philosopically, the state of law requires the constitution supremacy. This supremacy as a consequence of having the state of law, and implementation of democracy in another side, because constitution is the implementation of the highest social contract (Asshiddiqie, 2008). Constitutionalism and democracy aim at limiting the power of the government and refuse the absolute power (Manan \& Magnar, 1993).

It is necessary to remember that the constitution is the foundation of democracy, and the authentic democracy is the democracy by law. In its practice, state of law should be democratic, while democratic state should be based on the law and the constitution. Without them, the law enforcement leads to anarchy, it is similiar with the law without democratic constitution system will lead to elitist and repressive law. The democracy based on the law is called by constitutional democracy with the main pillar of democratic law.

State of law, constitution and democracy as discussed above become the main gate to the state order that respect constitution supremacy and democracy based on law. That is why the principle of the state of law should not be implemented by ignoring the principle of democracy which are regulated in the consitution.

Essentially, the concept of democratic state consists of two meanings: first, the existence of democracy as a political system in relation with decision making process, second: appreciating the constitution. In fact, to know wether the state is democratic or not, it can be traced from its state constitution because the constitution for a certain state is a judicial contract, political, and sociologically the pillars of the state in relation among the state institutions and within the citizens.

Being democratic state should be situated in the law corridor appropriately, unless the democracy will be misleading because the law is interpreted by the authorities lonely on behalf of democracy itself. If it occured to a certain state which declaring state of law, authomatically that state will fell down. The right democracy is the democracy with the law. Therefore, the idea of democracy and nomocracy should be in line, so that the state can be called as the state of law. Discussion on the democracy can not be separated from the constitution because the constitution itself is a part from the law. 
Positioning the Pancasila state of law in the context of democracy is really necessary and it should be maintained in state and nation wide. The Pancasila state of law can not be effective without its application among the society as well as a nomocracy should be maintained. The existence of nomocracy is as a living law, though practically their values can not be denied in the practice of state order in relation with democracy in Indonesia.

The concept of democracy will always put the poeple at the strategic position in state order practice. The practice can be varied from one state to another. The variation of democracy in practice arising the terminologies like Constitutional Democracy, Parlementer Democracy, Guided Democracy, the Pancasila Democracy, Populer Democracy, Soviet Democracy, National Democracy and etc. (Muntoha, 2009). Although the idea of the state of law has not been formulated explicitaly before the amandement of the verses of the 1945 acts, but its explanation underlines that Indonesia believes in the idea of Rechsstaat not machtssaat. While in the Consitutution of Temporary Republic of Indonesia (RIS) 1949, the idea of state of law explicitally elaborated as well as in Indonesia's Temporary acts of 1950 clearly stated. Furthermore, it can be found at the third amandement in 2001 on the 1945 acts, the consideration of the state of law is restated clearly at act no 1 verse 3 stating, "that Indonesia state is the state of law".

\section{CONCLUSION}

To sum up the explanation above, the Pancasila state of law recognizes the theological values as stated at the first part of Pancasila- the substance of islamic nomocracy. Democracy is single entity and undivided to build a state of law based on the Pancasila state of law and Islamic Nomocracy. Therefore, the principles of democratic state of Indonesia are avoiding the abuse of power to protect civil right and freedom. The theological values embedded in the first part of Pancasila and nomocracy of Islam should not be merely a formal regulation, furthermore it should address the more substantial Indonesian democracy. The state of law should be strengthened with democracy for they both have clear correlations. The state of law depends on constitutions and the people supremacy depends on system of democracy. In democratic system, people participation become the essence of the democracy. Democracy without the regulation of law will be misleading and blur, while the law without democracy will be meaningless. The Pancasila state of law without nomocracy of Islam will lose the theological values as the state identity and nomocracy without democracy will become the state of theocracy.

\section{References}

Al-Atok, A. R. (2016). Negara Hukum Indonesia. Malang: Universitas Negeri Malang. Asshiddiqie, J. (2008). Pokok-Pokok Hukum Tata Negara Indonesia Pasca Reformasi. Jakarta: Bhuana Ilmu Populer.

Asshiddiqie, J. (2010). Konstitusi \& Konstitusionalisme Indonesia. Jakarta: Sinar Grafika.

Azhari, M. T. (2015). Negara Hukum: Suatu Studi Tentang Prinsip-Prinsipnya Dilihat 
Dari Segi Hukum Islam Pada Periode Negara Madinah dan Masa Kini. Jakarta: Kencana.

Chandranegara, I. S. (2015). Fungsi Falsafah Negara Dalam Penerapan Konsep Negara Hukum. Jurnal Cita Hukum, 1(1).

Dayanto. (2013). Rekonstruksi Paradigma Pembangunan Negara Hukum Indonesia. Jurnal Dinam, 13(3), 498-509.

Djafar, W. (2010). Menegaskan Kembali Komitmen Negara Hukum: Sebuah Catatan atas Kecenderungan Defisit Negara Hukum di Indonesia. Jurnal Konstitusi, 7(5), 151-174.

Effendi, M. (2005). Kejaksaan RI: Posisi dan Fungsinya Dari Perspektif Hukum. Jakarta: Gramedia Pustaka Utama.

Fuady, M. (2009). Teori Negara Hukum Modern (Rechtstaat). Bandung: Refika Aditama.

Hakim, L. (2010). Kedududkan Hukum Komisi Negara di Indonesia: Eksistensi KomisiKomisi Negara (State Auxiliary Agency) Sebagai Organ Negara yang Mandiri Dalam Sistem Ketatanegaraan. Malang: PPS Universitas Brawijaya.

Mahendra, Y. I. (1996). Dinamika Tata Negara Indonesia; Konfilasi Aktual Masalah Konstitusi Dewan Perwakilan dan Sistem Kepartaian. Jakarta: Gema Insani.

Mahfud MD, M. (2010). Konstitusi dan Hukum Dalam Kontroversi Isu. Jakarta: Rajawali Press.

Manan, B., \& Magnar, K. (1993). Beberapa Masalah Hukum Tata Negara Indonesia. Bandung: Alumni.

Muntoha. (2009). Demokrasi dan Negara Hukum. Jurnal Administrasi Publik, 16(3), 379-395.

Nurita, R. F. (2015). Kajian Filsafat Hukum Tentang Demokrasi Di Indonesia. Jurnal Cakrawala Hukum, 6(1), 89-98.

Putra, I. K. C. (2017). Relevansi Konsep Negara Hukum Pancasila dengan Welfare State dalam Implementasinya dengan Pelayanan Publik di Indonesia. Jurnal Magister Hukum Udayana, 6(1), 1-12.

Rahardjo, S. (2006). Ilmu Hukum. Bandung: Citra Aditya Bhakti.

Sarip. (2018). Kebaruan dan Pembaharuan HukumPercepatan Ekonomi Digital Desa Dalam Bingkai Negara Hukum. Justitia Jurnal Hukum, 2(1), 1-17.

Sigit Riyanto. (2012). Kedaulatan Negara dalam Kerangka Hukum Internasional Kontemporer. Yustisia, 84(3), 5-14.

Soemarsono, M. (2007). Negara Hukum Indonesia Ditinjau Dari Sudut Teori Tujuan Negara. Jurnal Hukum \& Pembangunan, 37(2), 300-322.

Syarkawi. (2012). Implementasi Musyawarah Menurut Nomokrasi Islam. Lentera, 12(1), 87-90.

Wahyono, P. (1986). Indonesia Negara berdasarkan Atas Hukum. Jakarta: Ghalia Indonesia.

Wijaya, M. H. (2015). Karakteristik Konsep Negara Hukum Pancasila. Jurnal Advokasi, 5(2), 199-214.

Yuli Isdiyanto, I. (2018). Problematika Teori Hukum, Konstruksi Hukum dan Kesadaran Sosial. Jurnal Hukum Novelty, 9(1), 54-69.

Zuhraini. (2014). Konstribusi Nomokrasi Islam (Rule of Islamic Law) Terhadap Negara Hukum Pancasila. Al-'Adalah, 12(1), 171-190. 